\title{
Characterization of the Polymerase Activity Associated with Cultured Peripheral Blood Mononuclear Cells from Patients with Kawasaki Disease
}

\author{
JANE C. BURNS, ALICE S. HUANG, JANE W. NEWBURGER, AMY L. REINHART, MARY M. WALSH, \\ SUSAN HOCH, AND DONALD Y. M. LEUNG \\ Divisions of Infectious Diseases and Allergy and Immunology, Departments of Pediatrics and \\ Microbiology[J.C.B., A.S.H., A.L.R., M.M.W., S.H., D.Y.M.L.], Harvard Medical School, and Department of \\ Cardiology[J.W.N.],. Children's Hospital, Boston, Massachusetts 02115.
}

\begin{abstract}
The particulate fractions of culture supernatants from peripheral blood mononuclear cells from 39 patients with Kawasaki disease (KD) were examined for the presence of particle-associated reverse transcriptase activity. The peak polymerase activity was significantly higher in cultures from KD patients compared to controls (mean $=6.4$ versus $3.6 \mathrm{pmol}$ of dTMP incorporated, $p=$ 0.001). PBMC cultured between the 3rd and 9th wk after onset of fever were most likely to be associated with reverse transcriptase activity. Peak polymerase activity was positively associated with older age $(r=0.41, p=0.01)$ and greater magnitude of the serum IgA response at 7-14 d after onset of fever $(r=0.45, p=0.01)$ and $\operatorname{IgM}$ response at 6-9 wk after onset of fever $(r=0.46, p=0.01)$. The appearance of enzyme activity was not associated with a decrease in viability of the cultured cells. A purified enzyme preparation showed radiolabel incorporation only with an RNA template with DNA primer. These data suggest that circulating mononuclear cells from KD patients may harbor a polymerase-associated agent and that these cells can be most readily detected in the early convalescent phase of KD from older patients who mount a marked humoral immune response. (Pediatr Res 27: 109-112, 1990)
\end{abstract}

\section{Abbreviations}

KD, Kawasaki disease

IVGG, intravenous $\gamma$-globulin

DTT, dithiothreitol

PBMC, peripheral blood mononuclear cells

$\mathrm{KD}$ is an acute systemic vasculitis of infancy and early childhood that is characterized by fever, rash, mucosal inflammation, and coronary artery damage in $15-25 \%$ of patients (1). The acute illness is marked by profound immunoregulatory changes that include a $\mathrm{T}$ cell lymphocytopenia, a decrease in $\mathrm{CD} 8^{+} \mathrm{T}$ cells, an increase in activated $\left(\mathrm{DR}^{+}\right)$circulating $\mathrm{CD} 4^{+} \mathrm{T}$ cells, and a marked polyclonal B cell activation $(2,3)$. The etiology of $\mathrm{KD}$ remains unknown. We postulated that a retrovirus with tropism for endothelial and lymphoid cells might explain the vasculitis

Received December 20, 1988; accepted September 1,1989.

Reprint requests Jane C. Burns, M.D., Center for Molecular Genetics UCSD School of Medicine M-034 La Jolla, CA 92037.

Supported by USPHS Grants HL01855, HL34545, HL-37260, AI-22058, RR02172, and The Charles H. Hood Foundation. and immunologic changes associated with the acute disease. A reverse transcriptase-like polymerase activity is associated with the particulate fraction of supernatants from cultured KD PBMC but not controls $(4,5)$. The polymerase activity is associated with particles of buoyant density $1.16-1.20 \mathrm{~g} / \mathrm{mL}$ of sucrose and can be transmitted and transiently expressed in the human lymphoblastoid cell lines HUT-78 $(4,5)$ and Molt-3 and Molt-4 (6). In this report, we extend these observations on the functional properties of the polymerase and describe the demographic features of its detection in PBMC culture supernatants from KD patients.

\section{MATERIALS AND METHODS}

Patients. The PBMC were cultured from $53 \mathrm{KD}$ patients referred to Children's Hospital, Boston, from March 1985 to July 1987. Assays on the PBMC culture supernatants from 14 of these patients have been previously reported (4). The PBMC culture results from the remaining 39 patients form the basis of this report. All patients met the clinical case definition for $\mathrm{KD}$ and were examined by one of the authors (J.C.B. or J.W.N.). Informed consent for phlebotomy was obtained from the parents of all patients. Serum levels of acute phase reactants l-antitrypsin, C-reactive protein), erythrocyte sedimentation rate (Wintrobe), white blood cell count with differential, $\mathrm{Hb}$, platelet count, and serum Ig levels were obtained on all patients before initiation of IVGG (Immuno AG, Vienna, Austria) within the first $10 \mathrm{~d}$ of illness, and again $4 \mathrm{~d}, 3-5 \mathrm{wk}$, and 6-9 wk after initiation of therapy. All patients were examined for the presence of coronary artery abnormalities by two-dimensional echocardiography performed serially at these same time points.

The 12 control patients were either pediatric patients with systemic onset juvenile rheumatoid arthritis $(n=7)$, polyarticular arthritis $(n=1)$, fever of unknown origin $(n=1)$, or healthy subjects $(n=3)$.

Cell culture and polymerase assay. The PBMC were separated from $10-15 \mathrm{~mL}$ of heparinized blood by Ficoll Hypaque density gradient centrifugation and cultured according to our previously reported protocol (4). Minor changes in culturing technique included the deletion of antibody to $\alpha$-interferon and stimulation of the separated cells with purified phytohemagglutinin (Wellcome Diagnostics, Research Triangle Park, NC) at $1 \mu \mathrm{g} / \mathrm{mL}$ at initiation of the culture. Cells were maintained in RPMI 1640 supplemented with $2 \mathrm{mM}$ glutamine, $10 \% \mathrm{FCS}$, and recombinant IL-2 at 2-3\% (Hy-Clone Laboratories, Logan, UT). Culture supernatants were collected at 3-to 4-d intervals and the PBMC maintained at $0.5-2.0 \times 10^{6}$ cells $/ \mathrm{mL}$. PBMC viability was 
monitored by vital dye exclusion with trypan blue $0.2 \%$. Culture supernatants were centrifuged at $9000 \times g$ for $15 \mathrm{~min}$, the supernatant decanted, and recentrifuged at $100000 \times g$ for 90 min (Beckman L8-55 ultracentrifuge; SW41 rotor; Beckman Instruments Inc., Fullerton, CA) or at $200000 \times g$ for $30 \mathrm{~min}$ (SW 50.1 rotor). The pellet was resuspended in buffer A [50 $\mu \mathrm{L}$ for SW 41 tubes, $15 \mu \mathrm{L}$ for SW 50.1 tubes; $50 \mathrm{mM}$ Tris base $\mathrm{pH}$ d8.0, $1 \mathrm{mM}$ DTT, $500 \mathrm{mM} \mathrm{KCl}$, and $0.25 \%$ (vol/vol) glycerol]. Samples were assayed immediately or stored at $-70^{\circ} \mathrm{C}$. Positive control supernatants were derived from the HTLV 1 cell lines MJ, HUT-102, and MT-2 (kindly provided by Dr. Myron Essex, Harvard School of Public Health, and by Drs. Flossie WongStaal and Robert Gallo, NIH). Reverse transcriptase was assayed by incubation of a $15-\mu \mathrm{L}$ sample with $40 \mu \mathrm{L}$ of a reaction mixture containing $0.125 \mu \mathrm{Ci}{ }^{32} \mathrm{P}-\mathrm{dTTP}$ or ${ }^{32} \mathrm{P}-\mathrm{dGTP}$ (Amersham Corp., Arlington Heights. IL; sp act $600-800 \mathrm{Ci} / \mathrm{mmol}$ ), $59 \mathrm{mM}$ Tris base $\mathrm{pH} 8.0,5.9 \mathrm{mM}$ DTT, $0.59 \%$ Triton-X 100, $12.5 \mu \mathrm{M}$ dTTP., $12.5 \mu \mathrm{M}$ dATP (Boerhringer-Mannheim, Indianapolis, IN), $0.073 \mu \mathrm{cg} / \mu \mathrm{L}$ poly(rA):oligo(dT) or poly(rC):oligo(dG) (Sigma Chemical Co., St. Louis, MO), and $7.5 \mathrm{mM} \mathrm{MgCl}_{2}$. The following reaction mixtures were used to measure different polymerase activities: DNA-directed DNA polymerase- $0.125 \mu \mathrm{Ci}$ ${ }^{32} \mathrm{P}$-dTTP, $40 \mathrm{mM}$ Tris $\mathrm{HCl} \mathrm{pH} 7.5,1 \mathrm{mM}$ EDTA pH 8.0, 1 $\mathrm{mM}$ DTT, $13 \mathrm{mM} \mathrm{MgC1} 1_{2}, 0.59 \%$ Triton-X 100, $12.5 \mu \mathrm{M}$ dTTP, $1.8 \mathrm{U} / \mathrm{mL}$ poly $(\mathrm{dA})$ :oligo(dT) (Sigma); terminal transferase as for reverse transcriptase except with $0.1 \mathrm{mM} \mathrm{MnC1}{ }_{2}$ substituted for $\mathrm{MgCl}_{2}$ and salmon sperm DNA $(50 \mu \mathrm{g} / \mathrm{mL})$ as template. Positive control enzymes included reverse transcriptase from the particulate fraction of HTLV 1 culture supernatants prepared as for the $\mathrm{KD}$ supernatants, terminal deoxynucleotidyl transferase from calf thymus (Pharmacia Fine Chemicals, Piscataway, NJ, $12.5 \mathrm{U} /$ reaction), and Escherichia coli polymerase I (Pharmacia, $2 \mathrm{U} /$ reaction). The dTMP incorporation (mean \pm SEM) for the particulate fraction of the HTLV 1 infected cell supernatants used as positive controls for each assay was $17.7 \pm 0.8 \mathrm{pmol}$ (MJ), $24.4 \pm 6.9$ pmol (HUT-102) and $18.2 \pm 6.9$ pmol (MT-2).

The reaction was stopped by addition of $10 \mu \mathrm{L}$ of $10 \mathrm{mM}$ disodium pyrophosphate and $10 \mu \mathrm{L}$ of yeast RNA $(1 \mathrm{mg} / \mathrm{mL})$. Incorporated ${ }^{32} \mathrm{P}-\mathrm{dTMP}$ was measured after trichloroacetic acid precipitation onto filters by counting in liquid scintillant (Biofluor, New England Nuclear, Cambridge, MA) (Beckman model LS-1801 scintillation counter). Picomoles of dTMP incorporated were calculated from the sp act of $300-850 \mathrm{cpm} / \mathrm{pmol}$. Background for each assay (buffer A alone) was subtracted from all results. For analysis, only PBMC cultures assayed at least twice for reverse transcriptase activity between the 6th and 18th $d$ in culture were included. The mean of duplicate assays on a single specimen was used for statistical analysis.

To concentrate the particulate fraction for sucrose density gradient centrifugation, pooled $\mathrm{KD}$ PBMC supernatants $(310$ $\mathrm{mL}$ ) were agitated with $155 \mathrm{~mL}$ of $30 \% \mathrm{wt} / \mathrm{vol}$ polyethylene glycol in $0.4 \mathrm{M} \mathrm{NaCl}$ and incubated at $4^{\circ} \mathrm{C}$ for $1 \mathrm{~h}$. The precipitate was collected by centrifugation at $2500 \mathrm{rpm} \times 30 \mathrm{~min}$ at $4^{\circ} \mathrm{C}$, resuspended in TN buffer $(10 \mathrm{mM}$ Tris $\mathrm{HCl} \mathrm{pH} \mathrm{7.6,100} \mathrm{mM}$ $\mathrm{NaCl}$ ), and re-centrifuged twice to remove traces of PEG. The pellet was resuspended in $100 \mu \mathrm{L}$ of TN, layered onto a linear $20-60 \%$ sucrose gradient in $\mathrm{TN}$, and centrifuged (Beckman SW50.1 rotor, $35000 \mathrm{rpm} \times 16 \mathrm{~h}$ at $4^{\circ} \mathrm{C}$ ). Fractions $10-15$, approximately $1.15-1.20 \mathrm{~g} / \mathrm{mL}$ of sucrose were pooled, diluted in $\mathrm{TN}$, and centrifuged at $200000 \times \mathrm{g}$. The pellet was resuspended in $150 \mu \mathrm{L}$ of buffer $\mathrm{A}$ and $15-\mu \mathrm{L}$ aliquots were assayed for comparison of template/primer specificities.

Statistical analysis. We compared groups with respect to continuous variables using $t$ tests for means. The paired difference in polymerase activity before and after IVGG treatment was tested using the Wilcoxon signed rank test. The association between continuous variables was analyzed with use of Pearson correlation coefficients. Regression analysis was used to explore the relationship between peak polymerase activity and age. Serum Ig levels were adjusted for age using " $z$ scores" expressed in SD units = (patient serum Ig concentration - age-specific mean age-specific $\mathrm{SD}$ ).

\section{RESULTS}

We established a total of 77 cultures from the PBMC of 39 patients with KD. Figure 1 depicts the mean pmol of dTMP incorporated for polymerase assays performed at 3- to 4-d intervals on PBMC cultures established at different times after onset of fever. Of the 23 patients who had PBMC cultures established during the acute phase of their illness (first $14 \mathrm{~d}$ after onset of fever), 16 patients were cultured before IVGG therapy, 17 after therapy, and 10 both before and after therapy. Polymerase activity was higher in the particulate fraction of PBMC cultured before as compared to after IVGG administration, but the difference did not attain statistical significance $(3.0 \pm 1.0$ versus 1.6 \pm 0.4 pmol of dTMP incorporated at the 10- to 13-d timepoint, $p=0.06$ ) (Fig. $1 A$ ). A marked increase in mean enzyme activity was noted 10-13 and 14-17 d after initiation of the culture for PBMC obtained in the early convalescent period (3-9 wk after onset of fever) (Fig. 1B). Some late convalescent cultures $(>10$ wk postonset of fever) showed enzyme activity but the group was not significantly different from controls.

The peak polymerase activity measured for each culture is shown in Figure 2. Regardless of interval between culture and illness onset, the peak polymerase activity was significantly higher among KD patients than controls (mean $=6.4$ versus $3.6 \mathrm{pmol}$ dTMP incorporated, $p=0.001$ ). Peak polymerase activity was highest in cultures obtained between the 3 rd and 9 th wk postonset of fever as compared to cultures obtained at earlier or later timepoints in the illness (see Fig. 2).

We explored whether peak enzyme activity was correlated with demographic characteristics (age, sex), laboratory measures of systemic inflammation (C-reactive protein, erythrocyte sedimentation rate, white blood cell count, and $\alpha-1$-antitrypsin), humoral immune response (total serum IgA, IgG, and IgM), or coronary artery abnormalities. Peak polymerase activity was positively associated with older age $(r=0.41, p=0.01)$. Partial correlation controlling for age also revealed a significant association between peak polymerase activity and greater magnitude of the serum IgA response at 7-14 $\mathrm{d}$ after onset of fever $(r=0.41, p=0.011)$ and IgM response at 6-9 wk after onset of fever $(r=0.46, p=$ 0.01 ). Patients demonstrated a marked humoral immune response in the early convalescent period with elevations of both serum IgA and IgM (corrected for age by $\mathrm{z}$ score: mean $\operatorname{IgA}=$ $2.0 \mathrm{SD}$ above the mean, mean $\operatorname{IgM}=3.1 \mathrm{SD}$ above the mean). No other variables showed a significant correlation with peak polymerase activity.

We monitored five cultures for enzyme activity and cell viability by vital dye exclusion to determine whether polymerase activity was associated with a decrease in cell viability. Figure 3 shows the mean pmol of dTMP incorporated and the mean cell viability at each time point. There was no change in overall culture viability at the time of maximal enzyme activity, suggesting that the polymerase activity was not a cellular enzyme liberated from dying cells. Indeed, as the overall viability of the culture declined, so did the polymerase activity.

The results of experiments to characterize the template specificity of the enzyme are given in Table 1 . Pooled supernatants from Kawasaki PBMC cultures were purified by density gradient centrifugation to reduce the risk of contamination by cellular polymerases. The activity measured in the presence of an RNA template with DNA primer [poly(rC):oligo(dG)] was abolished both by omission of template/primer and by substitution of a DNA template with a DNA primer or a DNA oligonucleotide. Similar results were obtained for reverse transcriptase from HTLV 1 culture supernatants. No evidence for a DNA-directed DNA polymerase or terminal transferase was found in the $\mathrm{KD}$ enzyme preparation. 


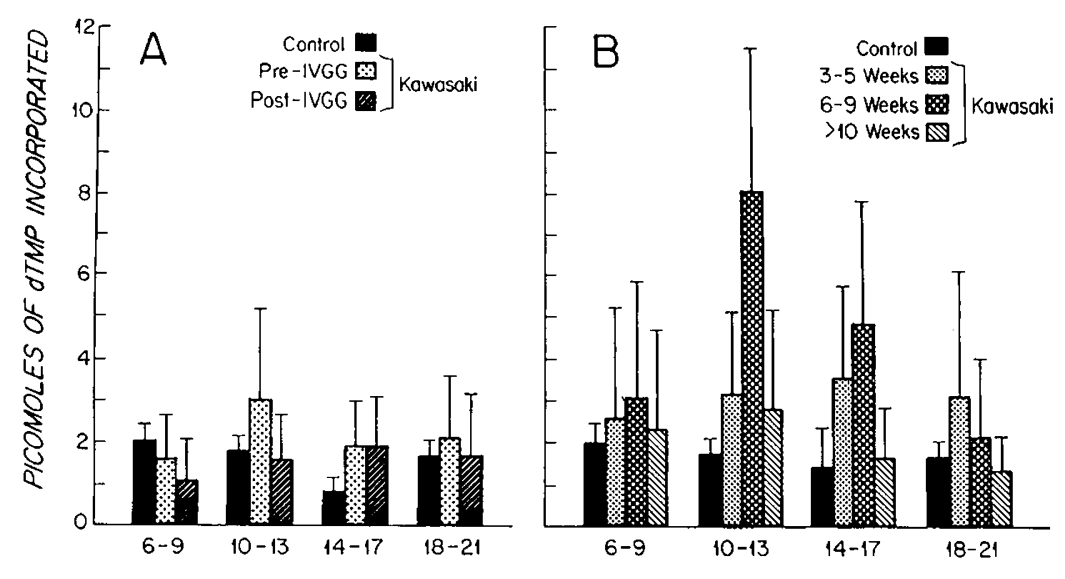

DAYS IN CULTURE

Fig. 1. Polymerase activity in the particulate fraction of PBMC culture supernatants. PBMC cultures from KD patients were established during the acute illness before therapy (pre-IVGG) and $4 \mathrm{~d}$ after initiation of therapy (post-IVGG) $(A)$ and at 3-5 wk, 6-9 wk, and $>10 \mathrm{wk}$ postonset of fever $(B)$. Bars represent mean pmol of dTMP incorporated +1 SE for polymerase assays performed at 3- to 4-d intervals. The control group $(n=$ $12)$ is the same in $A$ and $B$. The means for the 14-to 17-d assays of the cultures obtained at 3-5 and 6-9 wk $(B)$ were significantly different from the control means ( $p<0.05$, two-tailed unpaired $t$ test).

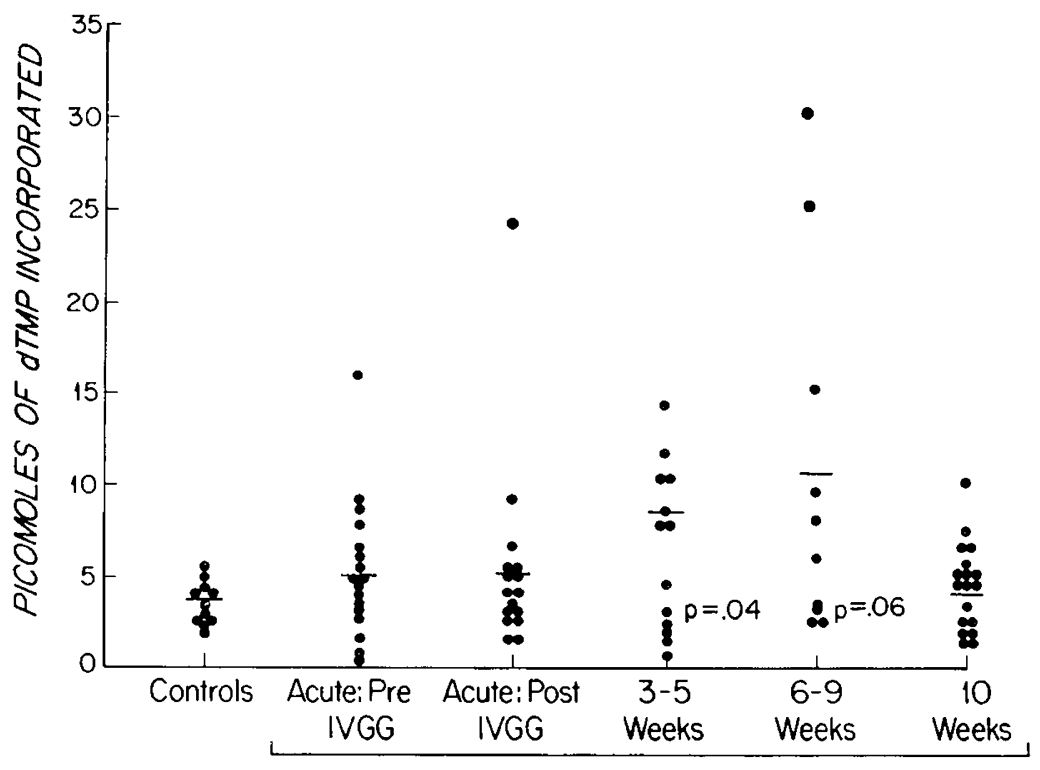

TIME POST-ONSET OF KAWASAKI DISEASE

Fig. 2. Peak polymerase activity in the particulate fraction of PBMC culture supernatants. Statistical comparisons are between mean pmol (bar) of dTMP incorporated at each time point postonset of fever and controls (two-tailed $t$ test).

\section{DISCUSSION}

This report extends previous observations of a reverse transcriptase-like enzyme activity associated with cultured KD PBMC $(4,5)$ and cocultures of KD PBMC with HUT-78, Molt3 , and Molt-4 cells (4-6). These data confirm earlier findings that low levels of enzyme activity are transiently expressed in the 2nd wk of culture $(4,5)$ and are associated with a particulate fraction of buoyant density $1.16-1.20 \mathrm{~g} / \mathrm{mL}$ of sucrose (4). Previously reported properties of the polymerase included heat lability, template/primer dependence, and a divalent cation dependence with a magnesium preference. In addition, a concentrated and sucrose density gradient purified preparation of the PBMC particulate fraction shows a preference for an RNA template with DNA primer. These characteristics are consistent with an RNA-directed DNA polymerase.

Other investigators have used different polymerase assays and have failed to detect polymerase activity above background lev- els. (5) Concern has also been raised that contaminating cellular DNA polymerases might account for the observed polymerase activity (5). Against this is the observation that overall cell viability does not change at the time of appearance of enzyme activity. Although cell viability declines after the $2 \mathrm{nd}$ wk in culture, there is no associated increase in enzyme activity coincident with increasing cell death. In addition, the concentrated enzyme fraction showed little polymerase activity in an assay with a DNA template and DNA primer under conditions that were optimal for another DNA polymerase $(E$. coli Polymerase I). Similarly, conditions that were optimal for terminal deoxynucleotidyl transferase did not favor incorporation of radiolabeled substrate by our particulate fraction. Finally, the detection of enzyme activity varied with the time of PBMC harvest postonset of disease and with patient age and magnitude of serum Ig response. These observations are difficult to understand if the enzyme activity is a random cellular contaminant.

The finding that the enzyme activity can be more easily 
112

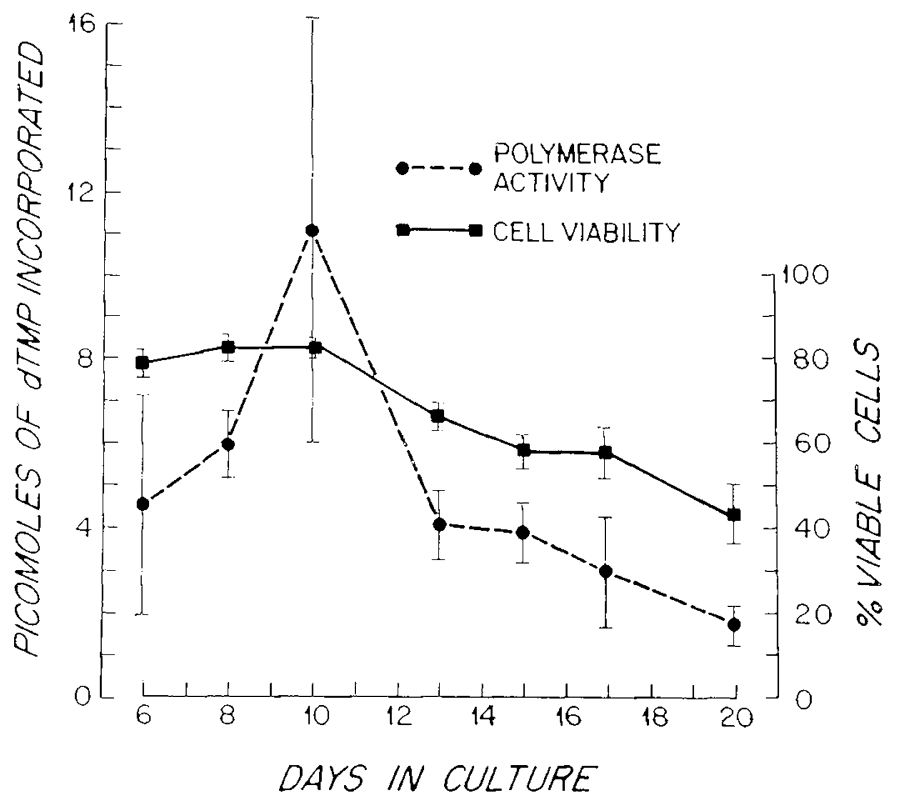

Fig. 3. Relationship of polvmerase activity in particulate fraction of KD PBMC culture supernatants to PBMC viability. Points represent mean of $5 \mathrm{KD}$ PBMC cultures $\pm 1 \mathrm{SL}$.

Table 1. Tomplate specificity of gradient purified enzlme pool*

\begin{tabular}{|c|c|c|c|}
\hline \multirow[b]{2}{*}{$\begin{array}{l}\text { Polymerase } \\
\text { source }\end{array}$} & \multicolumn{2}{|c|}{ Experimental Condition } & \\
\hline & $\begin{array}{c}\text { Poly(rC) :oligo(dG) } \\
+\quad \mathrm{PdCTP}\end{array}$ & $\begin{array}{c}\text { Poly (dA }) \text { oligo(dT) } \\
+ \text { P (ITTP }\end{array}$ & $\begin{array}{l}\text { Oligo(dT) } \\
+2 \mathrm{P} \text { dTTP }\end{array}$ \\
\hline $1112 V 1$ & $16.7+$ & 3.1 & 1.4 \\
\hline Kawasaki pool & 15.7 & 3.4 & 2.9 \\
\hline $\begin{array}{l}\text { Terminal trans- } \\
\text { ferase }\end{array}$ & $\mathrm{ND}$ & VD & 96.6 \\
\hline E coli Pol I & VD & 3730.0 & VD \\
\hline Buffer A & 3.0 & 0.9 & $N D$ \\
\hline
\end{tabular}

* Incorporation of radiolabeled substrate was measured under difterent experimental conditions (see text) with /) enzyme pooled from the particulate fraction of HTLV I or KD PBMC culture supernatants. 2) puritied terminal transferase. or i) fic coli polymerase 1 .

tpmol of labelled dGMP or dTMP incorporated using indicated templateprimer combination. Buffer $A$ backgrond not subtracted.

detected in cultured PBMC from patients in the carly convalescent stage of their illness suggests that the enzyme may be associated with a subset of the PBMC that is underrepresented during acute disease. The observed events could be explained by lytic infection of a small subpopulation of cultured cells with release of viral particles after $7-14 \mathrm{~d}$ in culture. Our methods would be unable to detect low levels $(<1: 100$ cells $)$ of cultured cell lysis and death.

Farly during acute KD, there is a $T$ cell lymphocytopenia, a low number of $\mathrm{CD}^{+}$suppressor cells, activation $\left(\mathrm{DR}^{+}\right)$of circulating $\mathrm{CD}^{+}$cells, and polyclonal $\mathrm{B}$ cell activation $(2,3)$. These findings are, at least transiently, reversed by the administration of IVGG (7). It is tempting to speculate that the decreased likelihood of polymerase detection immediately after IVGG administration and the increased likelihood of enzyme detection in PBMC harvested from patients in the early convalescent period, may be related to the dramatic fluxes in immune effector cell number and function. The decreased ability to detect the enzyme activity in cultures obtained bevond 6 mo after the disease may be related to host immune surveillance and elimination of infected cells from the circulating population or development of latent infection.

The association of polymerase activity with PBMC cultured from older patients and patients with a more profound serum $\operatorname{IgM}$ and $\operatorname{IgA}$ response is intriguing. Marked polyclonal B cell activation occurs during acute KD and elevated spontaneous secretion of $\operatorname{Ig} G, \operatorname{IgM}(2,7,8)$, and $\operatorname{Ig} A(9)$ has been demonstrated. Although treatment with high dose IVGG reverses the B cell activation measured in vitro immediately after therapy (7), serum levels of $\operatorname{lgM}$ and $\operatorname{Ig} A$ are still significantly elevated when measured 3-5 wh postonset of fever (J Burns, unpublished data). The association of this $B$ cell activation with detection of polvmerase activity suggests several hypotheses. One is that, like Epstein Barr virus infection. polvclonal $B$ cell activation results from direct infection of B cells (10). Conversely, as is suspected in other viral infections including HIV infection (11), polyclonal B cell activation occurs without direct infection of $B$ cells via different immunoregulatory pathways.

In summary. evidence is provided for a particle-associated polymerase with many characteristics of an RNA-directed DNA polymerase that is associated with cultured PBMC from Kawasaki patients. These data suggest that a subset of circulating mononuclear cells may harbor a polymerase-associated agent and that these cells can be most readily detected during the early convalescent phase of KD from older patients with a more marked humoral immune response.

\section{RIIIREVOES}

1. Kawasaki T. Kosaho I: Okawa S. Shigomatsu I. Yanagawa H 1984 A now infantile acute febrile mucocutaneous lymph node syndrome (MCLVS prevaling in Japatr. Podiatrics 54:271-276

2. Leung DYM. Siegel RI. Grady SR, Krensty A. Meade R. Reinhery EL, Geha RS 1982 Immunoregulatory abnormalities in MCINS. Clin Immunol and Immunopathol 23:100-112

3. Leung DYM. Chu F.T. Wood $\backslash$ Grady S. Mcade R. Geha RS 1983 Immunoregulatory T ceil abnomalities it MCLNS. J Immunol 130:2002-20)4

4. Bums IC, Goha RS. Schneberger EE. Rosen FS, Glezen LS. Huang AS. Natale J. Ieung DYM. Newburger IV 1986 Polymerase activity in lymphocyte culture supernatants from patients with Kawasaki disease. Vature $323: 814$ 816

5 Melish M. Marchette N. Kaplan JC. Kihara S. Ching D. Ho D 1989 Absence of significant RNA-dependent DNA polvmerase activity in lymphocutes from patients with Kawasaki syndrome Nature $337: 288-290$.

6. Shumar ST, Rowley $A H 1980$ Does Kawasaki disease have a retrovira actiology? Iance $2: 545-546$

7. Leung D) M. Burns IC. Newburger IW, Rosen FS. Geha RS 1987 Reversal of lymphocyte activation in vivo in Kawasaki syndrome by intravenous gammaglobulin. J Clin Invest $79: 468-472$

8. Kuno-Sakai H 1985 Increase of immunoglobulin-bearing peripheral blood lymphocytes in children with Kawasaki disease. Acta Paediatr Ipn 27:127130

9. Ohshio G. Furukawa I. Khine M. Yoshioka H. Kudo Il. Hamashima Y 1987 High lesels of led-containing circulating immune complex and secretory IgA in Kawasaki discase. Microbiol Immunol 31:891-898

10. Bird AC. Britton $S 1979$ A new approach to the study of human B lymphocyte function using an indirect plaque assav and a direct $B$ cell activator. Immunol ReV 45:41-67 